\title{
三軸圧縮下のコンクリートの応力〜ひずみ関係 STRESS-STRAIN RELATIONSHIP FOR CONCRETE UNDER TRIAXIAL COMPRESSION
}

\author{
長 沼一洋* \\ Kazuhiro NAGANUMA
}

\begin{abstract}
A stress-strain relationship for concrete under triaxial compression is proposed for the analysis of confined concrete. The applicability of the existing failure criteria and equations for the stress-strain curve is discussed in comparison with the experimental results obtained from the past triaxial compression tests. It is demonstrated that the ascending and the descending parts of the stress-strain curve of concretes with different compressive strengths under various. confining stresses can be represented well by the existing formula using proposed coefficients calculated as functions of the uniaxial compressive strength and strength enhancement ratio.
\end{abstract}

Keywords : compressive strength, failure criterion, strain softening, confining effect, lateral pressure 王縮強度，破壊基準，ひずみ軟化，拘束効果，側圧

1.はじめに

鉄筋コンクリート柱や鋼管コンクリート柱のように、 鋼材等により拘束された部材におけるコンクリートの 圧縮特性は、拘束度に応じて強度と勒性が大きく変化す ることが知られている。このようなコンクリートは一般 に三軸圧縮状態にあり、その応力〜ひずみ関係は一軸 圧縮試験から得られるものとはかなり異なることが既往 の数多くの実験で示されている。三軸圧縮下のコンク リートの応力〜ひずみ関係を簡潔に表現することができ れば、帯筋や鋼管で拘束される部材の酎力ゃ变形能を 解析的に評価する上で極めて有益と思われる。

三軸圧縮下のコンクリートの応力〜ひずみ関係は、 最近の Maekawaら ${ }^{11-31}$ の弾塑性破壊モデルや、水野

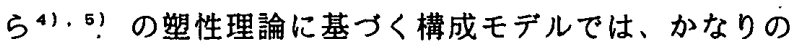
精度で実験結果を再現でることが示されており、帯筋 や鋼管による拘束効果の解析例も報告されている ${ }^{31}$ 》。 しかし、拘束されたコンクリートの応力〜ひずみ関係は 陽な形では表現されていない。

コン.クリートの三軸圧縮下の応力〜ひずみ関係を拘束 応力の関数として表現したものとしては、㚼中ら が側压（拘束応力）が比較的低い場合を対象として、
実験結果と良好に対応するモテルを提案している。その 他にも幾つかの提案 ${ }^{101,211}$ があるが、適用性に関して は十分な検討がなされていないものが多い。また、既往 の提案モデルの相互比較や、様、々な実験結果との対応性 等が検討された例も少ない。

本論文は、鋼材等により拘束される部材の解析に用い ることができるコンクリートの三軸压縮下での応力〜 ひずみ関係の簡潔な表現式を得ることを目的として、 三軸厈箖下での強度、強度時のひずみ、軟化域を含めた 応力〜ひずみ関係に関し、既往の样々な実験結果と提案 モデルを比較して、各モデルの適用性を調べると共に、

新たな提案を行ったものである。

\section{2.三轴压蟌下のコンクリートの破㙼基準}

三軸圧縮下の応力〜ひずみ関係を表現する場合、先ず 最大応力点を決定する必要がある。一般に最大応力（強 度)は主応力の関数で表現され、主応力空間内で強度に 到達する点の集合は破壊曲面と呼ばれている。図 1 に コンクリートの破壤曲面の概念を示す。なお、破壊曲面 を記述するための用語と記号の定㼁は以下の通りであ 
$\eta 、 \sigma_{1} 、 \sigma_{2} 、 \sigma_{3}$ は主応力で、压縮を正とする。

静水圧軸 : 主応力空間で $\sigma_{1}=\sigma_{2}=\sigma_{3}$ となる軸 偏差平面 : 主応力空間で静水圧軸に淔交する平面 子 午 面 : 主応力空間で静水圧軸を含む平面

子 午 線: 子午面と破壤曲面の交線

応力の一次不変墨： $I_{1}=\sigma_{1}+\sigma_{2}+\sigma_{3} \cdots \cdots(1)$

偏差応力の二次不変量 : $\mathrm{J}_{2}$

$$
\mathrm{J}_{2}=1 / 6 \cdot\left[\left(\sigma_{1}-\sigma_{2}\right)^{2}+\left(\sigma_{2}-\sigma_{3}\right)^{2}+\left(\sigma_{3}-\sigma_{1}\right)^{2}\right]
$$

静水压成分を表わす量 $: \xi=I_{1} / \sqrt{3} \cdots \cdots \cdots \cdots(3)$

偏差成分を表わす量： $r=\sqrt{2 J_{2}} \cdots \cdots \cdots(4)$

倨差平面上の位置を表わす量 : $\theta$ (相似角)

$$
\cos \theta=\frac{2 \sigma_{1}-\sigma_{2}-\sigma_{3}}{2 \sqrt{3 \mathrm{~J}_{2}}} \quad(0 \leqq \theta \leqq 60) \cdots(5)
$$

引張子午線 : $\theta=0$ 度 $\left(\sigma_{1}=\sigma_{2}>\sigma_{3}\right)$ の子午線

厌樎子午線 $: \vdots \theta=60$ 度 $\left(\sigma_{1}>\sigma_{2}=\sigma_{8}\right)$ の子午線

八面体垂直応力： $\sigma_{o c t}=I_{1} / 3 \quad \cdots \cdots \cdots \cdots(6)$

八面体せん断応力： $\tau_{0 \circ \mathrm{t}}=\sqrt{2 / 3 \mathrm{~J}_{2}} \cdots \cdots \cdots$ (7)

既往の代表的な破壤基準の特徽を表 1 に示す。コンク リートの圧縮強度は一軸より二軸、二軸より三軸状態で より高くなることから、その破壤基準は静水压成分と 中間主応力に依存することが明らかである。さらに、 多くの実験結果より、コンクリートの破壊曲面は図 1 に 示すように、曲線の子午線と非円形の偏差平面を有する

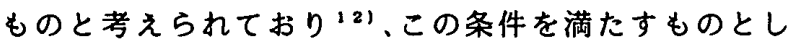
て、0ttosen の基準 $(4 \text { バラメータモデル })^{131}$ 、あるい はWillam-Warnkeの基準（5パラメータモデル) ${ }^{14}$ が適 していると言える。この 2 つの破壇基準の違いは、 4 バ ラメータモデルでは引張子午線と圧縮子午線が相似形で あるのに対して、5パラメータモデルではその制約が無 い点である。これらの基準は以下のように表現される。

.0ttosen の破壊基準（4 バラメータモデル)

$A \cdot \frac{J_{2}}{\sigma_{B}{ }^{2}}+\lambda \cdot \frac{\sqrt{J_{Z}}}{\sigma_{B}}+B \cdot \frac{I_{1}}{\sigma_{B}}-1=0 \cdots(8)$

$\lambda=K_{1} \cdot \cos \left[\frac{1}{3} \cos ^{-1}\left(K_{2} \cdot \cos 3 \theta\right)\right](\cos 3 \theta \geq 0)$

$\lambda=K_{1} \cdot \cos \left[\frac{\pi-\cos ^{-1}\left(-K_{2} \cdot \cos 3 \theta\right)}{3}\right](\cos 3 \theta<0)$

$\sigma_{\mathrm{B}}:$ 一軸压縮強度

$\mathrm{A}, \mathrm{B}, \mathrm{K}_{1}, \mathrm{~K}_{2}$ : 材料試験結果から決まる係数

-Willam-Warnke の破壞基準（ 5 バラメータモデル） $\tau_{\text {oct }}=\frac{2 B\left(B^{2}-A^{2}\right) C^{2}+B(2 A-B) \sqrt{4\left(B^{2}-A^{2}\right) C^{2}+5 A^{2}-4 A B}}{4}$

$A=\left[a_{0}+a_{1}\left(\sigma_{0} c_{t} / \sigma_{B}\right)-a_{2}\left(\sigma_{O C} / \sigma_{B}\right)^{2}\right] \cdot \sigma_{B}$ ........ (12)

$B=\left[b_{O}+b_{1}\left(\sigma_{o c t} / \sigma_{B}\right)-b_{2}\left(\sigma_{O C t} / \sigma_{B}\right)^{2}\right] \cdot \sigma_{B}$ ........ (13)

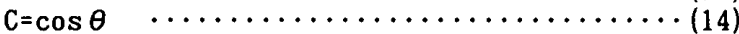

$a_{0}, a_{1}, a_{2}, b_{0}, b_{1} ， b_{2}$ : 材料試験結果から決まる係数

ここで、破㗒曲面の形状を決定するための係数が問題 となる。0ttosen ${ }^{(3)}$ は一軸圧縮強度に対する引張強度

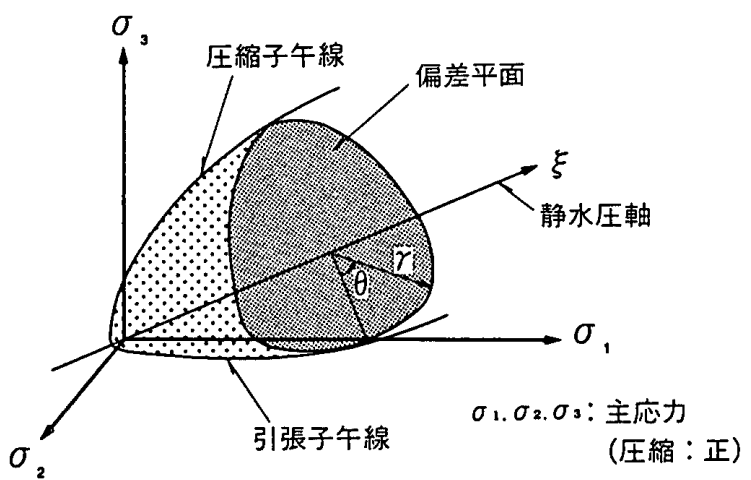

図 1 主応力空間における破壊曲面の概念

\begin{tabular}{|c|c|c|c|c|}
\hline 破壊基準 & $\begin{array}{l}\text { 子午線 } \\
\text { の形状 }\end{array}$ & $\begin{array}{c}\text { 谝差平面 } \\
\text { の形状 }\end{array}$ & $\begin{array}{l}\text { 静水王 } \\
\text { 依存性 }\end{array}$ & $\begin{array}{c}\text { 中間主応力 } \\
\text { 依存性 }\end{array}$ \\
\hline von Mises & 直 線 & 円形 & 無 & 有 \\
\hline Mohr-Coulomb & 直 線 & 六角形 & 有 & 無 \\
\hline Drucker-Prager & 㨁 線 & 円形 & 有 & 有 \\
\hline Chen and Chen & 曲 線 & 円形 & 有 & 有 \\
\hline Ottosen & 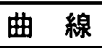 & 非円形 & 有 & 有 \\
\hline Willam-Warnke & $\begin{array}{ll}\text { 曲 線 } \\
\end{array}$ & 非円形 & 有 & 有 \\
\hline
\end{tabular}

表 1 既往の主な破壇基準の特徵 ${ }^{121}$

\begin{tabular}{|c|c|c|c|c|c|}
\hline 提 & 案 & A & B & $K_{1}$ & $K_{2}$ \\
\hline 0 ttosen ${ }^{131}$ & $: \sigma_{t} / \sigma_{B}=0.08$ & 1.808 & 4.096 & 14.49 & 0.9914 \\
\hline " & $: \sigma_{t} / \sigma_{\mathrm{B}}=0.10$ & 1.276 & 3.196 & 11.74 & 0.9801 \\
\hline " & $: \sigma_{t} / \sigma_{B}=0.12$ & 0.922 & 2.597 & 9.911 & 0.9647 \\
\hline \multicolumn{2}{|c|}{ Hatanaka $5^{181}$} & 1.256 & 4.030 & 14.63 & 0.9870 \\
\hline
\end{tabular}

表 2 0ttosen の 4 バラメータモデルの係数

$\left(\sigma_{t}\right)$ の比が、0.08,0.1,0.12の3 種類の場合につい て、既往の低側圧から高側圧の三軸王縮試験の結果に 基ついて 4 パラメータモデルの係数を決定している。

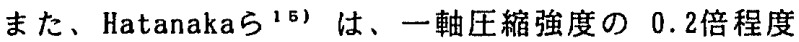
までの比較的低侧圧下での三軸圧縮試験の結果に基つい て、4 バラメータモデルの係数を決定している。これら の值を表 2 に示す。 4 パラメータモデルでは三軸压縮下 での強度は $\sigma_{t} / \sigma_{\mathrm{B}}$ の比の違いによる影響をほとんど受 けないことが分かっている13。一方、5パラメータモデ ルに関しては、E1wiとMurray ${ }^{16)}$ は、既往の二軸圧縮試 験、及び三軸圧縮試験の結果に合わせて係数を決定して いる。また、大沼・青柳 ${ }^{17)}$ は、一軸圧縮強度の 3 倍程 度までの高㑡圧下での三軸圧縮試験の結果に基ついて、 5 バラメータモデルの係数を決定している。これらの值 を表 3 に示す。

ここで、 4 バラメータモデルと 5 パラメータモデルに 関して、それぞれに既往の提案による係数を用いた場合 の破壊曲面の形状を比較してみる。目 2 は柱部材などに おいて拘束を受けるコンクリートの応力状態に近い圧縮 子午線上の実験データ $\left(\sigma_{2}=\sigma_{3}\right.$ の側圧下で $\sigma_{1}$ を增大 
表 3 Willam-Warnke の5バラメータモデルの係数

\begin{tabular}{|c|c|c|c|c|c|c|}
\hline 提 案 者 & $a_{0}$ & $a_{1}$ & $a_{2}$ & $b_{0}$ & $b_{1}$ & $b_{2}$ \\
\hline Elwi, Murray ${ }^{18)}$ : Kupfer $5 の$ 実験 & 0.0630 & 0.6627 & -0.0494 & 0.1136 & 1.1737 & -0.3005 \\
\hline : Schickert らの実験 & 0.0692 & 0.6611 & -0.0493 & 0.1230 & 1.1505 & -0.3155 \\
\hline 大沼 · 青柳 ${ }^{171}$ & 0.0689 & 0.6868 & -0.0964 & 0.2040 & 0.8424 & -0.1204 \\
\hline
\end{tabular}

させ破壊させたもの）と、各係数による压縮子午線の 形状の違いを比較したものである。実験データは以下の ものをプロットしている。

- Richart 5(文献12の図5-5より)

- Balmer（文献12の国5-5より)

- Chinn, Zimmerman (文献12の図5-21より)

- Schickert, Winkler (文献16のFig.5より)

- 大沼, 青柳 ${ }^{171}$

- Mills, Zimmerman ${ }^{18}$

- Palaniswamy, Shah' ${ }^{10)} \cdot$ Gardner ${ }^{20)}$

-山口, 策本, 野村 ${ }^{211} \cdot$ Kotsovos, Newman ${ }^{21}$

- 㚼中ら (1), 8), 23), 24)

柱部材において、コンクリートが鋼材から受ける側王 のレベルは、既往の鋼管コンクリートの実験 ${ }^{251}$ では $300 \mathrm{kgf} / \mathrm{cm}^{2}$ 程度に達し、コンクリートの強度は一軸圧縮 強度の 3 倍程度まで增大することが示されている。この 場合には $\xi / \sigma_{\text {B }}$ かおよそ $2 \sim 3$ 程度となる。一方、 帯筋に上る拘束を受ける場合は側厈が不均一になり、 平均するとおよそ $20 \mathrm{kgf} / \mathrm{cm}^{2}$. 以下と言われておりい、 概ね一軸王縮強度の $1 \sim 2$ 倍の強度が得られている201。

图 2 (a) より、4 バラメータモデルでは $\xi / \sigma_{\mathrm{B}}$ の 增大に伴って偏差平面も拡大するが、5バラメータモデ

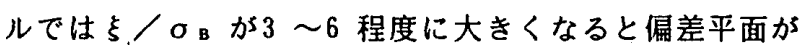
小さくなり始める点に大きな違いがあることが分かる。 また、 4 パラメータモデルでは $\xi / \sigma_{\mathrm{B}}$ が10を越えるよ うな超高側圧下の実験データにも比較的対応している。 図 2 (b) より、乡 データのバラッキが大きくなり、特に異なるシリーズ間 で差が見られる。このことは、コンクリートの調合、

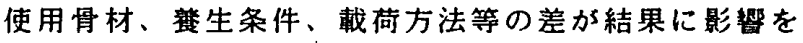
及ぼしている可能性を示唆するもので、係数の誘導の基 礎とする実験データが異なれば、係数も变わり得ること を意味する。筆者が調べた限りでは、これらのシリーズ 間の差を説明できる諸条件の差は見出せなかった。

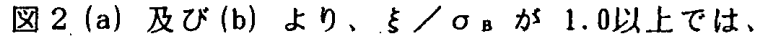
大沼らの係数を用いた 5 パラメータモデルが実験データ の下限を表現しており、㚼中らの係数を用いた 4 バラ メータモデルが概极実験データの上限を表現していると 言える。图 2 (c) に示した $\xi / \sigma_{\text {B }}$ が1.3 以下の領域で は、いずれのモデルもほぼ線形で、4バラメータモデル の方が 5 バラメータモデルより勾配が多少大きい。帯筋 等の拘束により、比較的低側圧を受けるコンクリートの 応力状態に近いと考えられる $\xi / \sigma_{\text {в }}$ が1.0 程度以下の

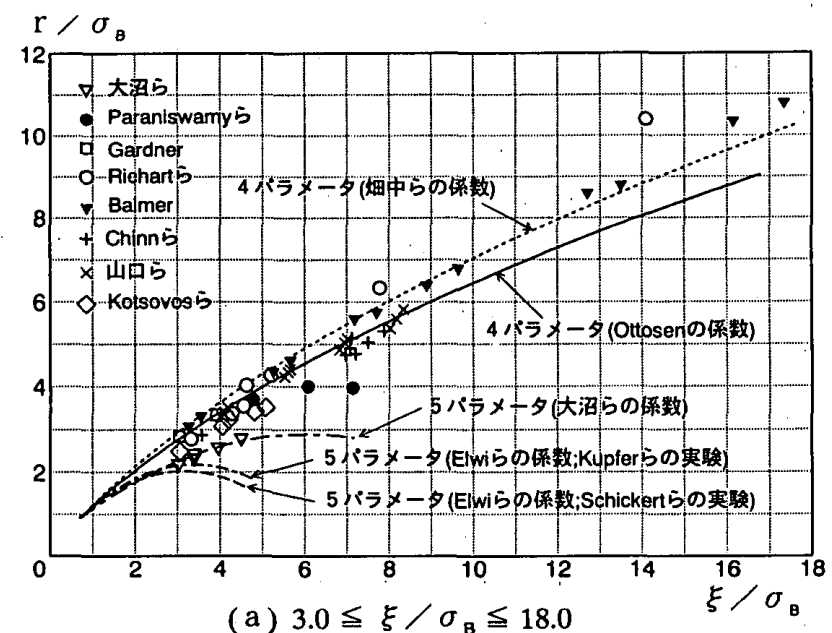

(a) $3.0 \leqq \xi / \sigma_{B} \leqq 18.0$
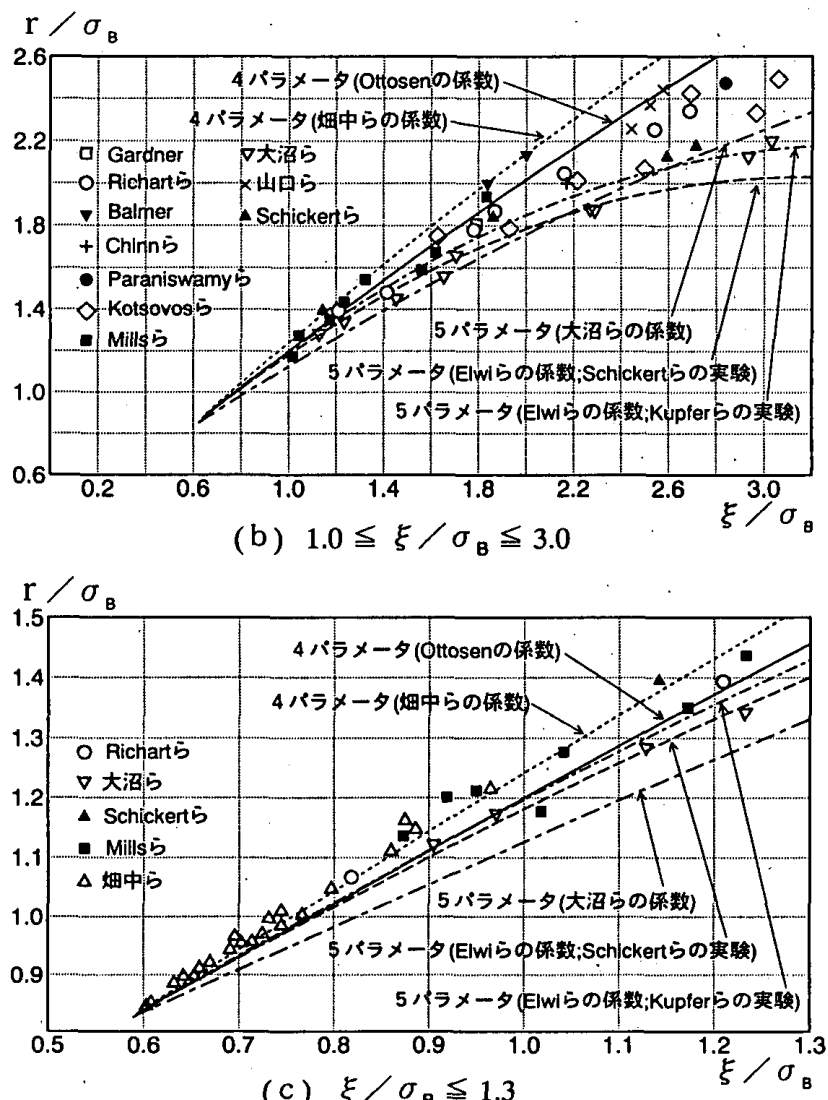

図2 压縮子午線上の実験データと既往の 破壊条件の圧縮子午線形状の比較

領域では、実験との対応性は畑中らの係数を用いた 4 バラメータモテルが最も良好と言える。このモテルの 場合、二方向に等しい側压 $\sigma_{\mathrm{r}}$ を受ける場合の強度 $\sigma_{\mathrm{P}}$ はおよそ次式で与えられる。

$$
\sigma_{P}=\sigma_{B}\left[1+5\left(\sigma_{r} / \sigma_{B}\right)^{0.77}\right]
$$


図 3 は偏差平面の形状を各モデルで比較したもので ある。 $\xi / \sigma_{B}=1.0$ の場合には各モデルの差がほとん ど見られず、偏差平面は三角形に近い形状を示すか、、 $\xi / \sigma_{\mathrm{B}}$ の值が大きくなると、 5 バラメータモデルの方 が 4 バラメータモデルより偏差平面が小さ、円形に 近ついている。

以上より、拘束を受けるコンクリートの三軸圧縮下の 破壤基準としては、比較的低側圧状態では㚼中らの係数 を用いた 4 バラメータモデルが適していると思われる。 しかし、側圧レベルが高くなると実験データのバラッキ が大きく、大沼らの係数を用いた 5 バラメータモデルが 下限值、姆中らの係数を用いた 4 バラメータモデルが ほほ上限値を表現しており、側圧レベルが高い場合には 既往の提案モデルの適用性を論じることは難しい。

\section{3.最大压綿応力時のひずみ}

多軸応力下において、一軸压樎强度を越える最大开縮 応力 $\left(\sigma_{p}\right)$ に対応するひずみ $(\varepsilon p)$ の評価式としては 以下の提案がある。

- Darwin $5^{27)}$ (二軸圧縮対象)

$\varepsilon_{\mathrm{P}}=\varepsilon_{\mathrm{B}}\left(3.15 \sigma_{\mathrm{P}} / \sigma_{\mathrm{B}}-2.15\right)$

$\varepsilon_{\mathrm{B}}$ : 一一軸压樎強度時のひずみ

- Richart $5^{28)}$ (三軸圧縮対象)

$\varepsilon_{P}=\varepsilon_{B}\left[1+5\left(\sigma_{P} / \sigma_{B}-1\right)\right]$

- Fafitis 5“1（三軸圧縮対象）

$$
\varepsilon_{P}=\varepsilon_{B}+0.0296 \sigma_{R} / \sigma_{B} \cdot\left[1+15\left(\sigma_{r} / \sigma_{B}\right)^{3}\right]
$$

$$
\sigma_{r} \text { : 等二軸例圧 }
$$

- 㚼中5 29 (低側圧三軸圧樎対象)

$$
\varepsilon_{P}=2 \varepsilon_{B}\left(I_{1+} / \sigma_{B}-1\right)+\varepsilon_{B}
$$

$I_{18}=\sigma_{p}+\sigma_{2}+\sigma_{3}$

$$
\sigma_{2}, \sigma_{3}: \text { 侧压 }
$$

・佐藤 ${ }^{301}$ (円形断面銅管コンクリート対象；正縮を正）

$\varepsilon_{p}=0.003+0.0002 \sigma_{r} \cdot e$

$\mathrm{C}=-0.0025 \sigma_{\mathrm{B}}$

- CEB-FIP MODEL CODE 1990 \$1)

$\varepsilon_{\mathrm{P}}=0.002\left(\sigma_{\mathrm{P}} / \sigma_{\mathrm{B}}\right)^{2}$

以上の式は、側王の関数で与えられるものと、強度 増大率 $\left(\sigma_{\mathrm{P}} / \sigma_{\mathrm{B}}\right)$ の関数で与えらるものに分けられる が、側圧の関数で与えられるものは最大压縮応力方向の ひずみの評価に限定されており、一般性を考えると、 強度增大率の関数で表現されている方が使いやすいと 言える。そこで、強度增大率の関数となっている3つの 提案式による評価精度を実験結果と比較したものを図 4 及び図 5 に示す。いずれも $\sigma_{\mathrm{P}} / \sigma_{\mathrm{B}}>1.0$ となる領域で 比較している。図4 はDarwinらとRichart らの提案式を 実験結果と比較したものである。実験では強度の增大よ

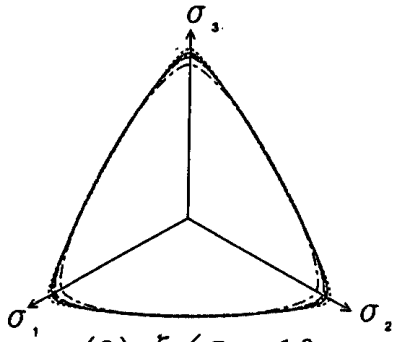

(a) $\xi / \sigma_{\mathrm{B}}=1.0$

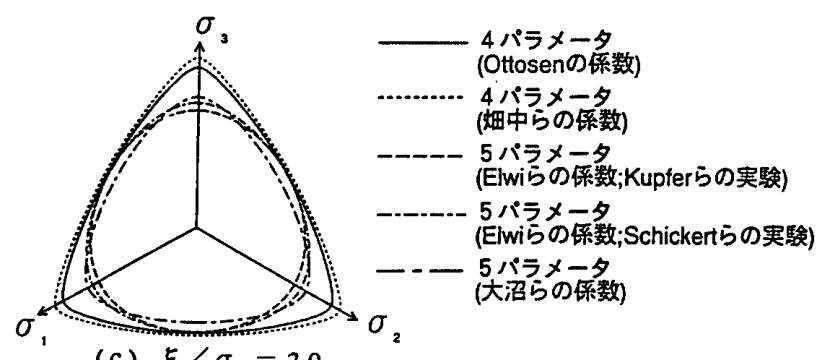

(c) $\xi / \sigma_{\mathrm{B}}=3.0$
り強度時のひずみの増加が顕著で、強度が 2 倍になると ひずみは約 4 倍、強度が 5 倍になるとひずみは20倍程度 に增加している。 $\sigma_{\mathrm{P}} / \sigma_{\mathrm{B}}$ の値が 3 以上では実験結果は ほとんどがRichart らとDarwinらの提案式の間に入り、 $\sigma_{\mathrm{P}} / \sigma_{\mathrm{B}}$ の值が 5 以上ではRichart らの提案式の方が 対応性がやや良好である。一方、 $\sigma_{\mathrm{P}} / \sigma_{\mathrm{B}}$ が 2 以下では Darwinらの提案式の方が実験結果と良く対応している。

図 5 はCEB-FIP の式を実験結果と比較したものであ る。実験結果にはパラッキが見られるが、CEB-FIP の式 は比較的対応性が良い。但し、CEB-FIP の式は $\varepsilon_{P}$ を 直接評価するようになっており、 $\sigma_{\mathrm{P}} / \sigma_{\mathrm{B}}=1.0$ の時に $\varepsilon_{\mathrm{p}}=0.002$ に固定されている点にやや問題がある。そこ て、式 (23)の係数 0.002 を $\varepsilon_{\mathrm{B}}$ に変えて、さらに、実験 データとの対応性を向上させるために、ベキ乗数を最小 自乗法により求めると次式が得られる。

$$
\varepsilon_{P}=\varepsilon_{B}\left(\sigma_{P} / \sigma_{B}\right)^{1.8}
$$

困 6 に式(24)と実験データを比較して示す。バラッキ がやや見られるものの、全般的にRichart らやDarwinら の評価式に比べて $\varepsilon_{\mathbf{p}}$ の評価精度が向上している。よっ て、三軸圧縮下における最大応力時のひずみの評価式と して、式(24)を提案する。

\section{4.三軸圧縮下の応カ〜ひずみ曲線}

畑中ら ${ }^{8) ， 91 は ~} 50 \mathrm{kgf} / \mathrm{cm}^{2}$ 程度までの低側圧を受け、 $\sigma_{\text {в }}$ が $1000 \mathrm{kgf} / \mathrm{cm}^{2}$ までのコンクリートを対象として、 主圧縮方向の応力〜ひずみ関係を次式に示すように、 上昇域をPopovics式 ${ }^{221}$ 、下降域（ひずみ軟化域）を修正 谷川式3) て表現することを提案している。(応力の符号 は圧縮を正とし、単位は $\mathrm{kgf} / \mathrm{cm}^{2}$ ) 


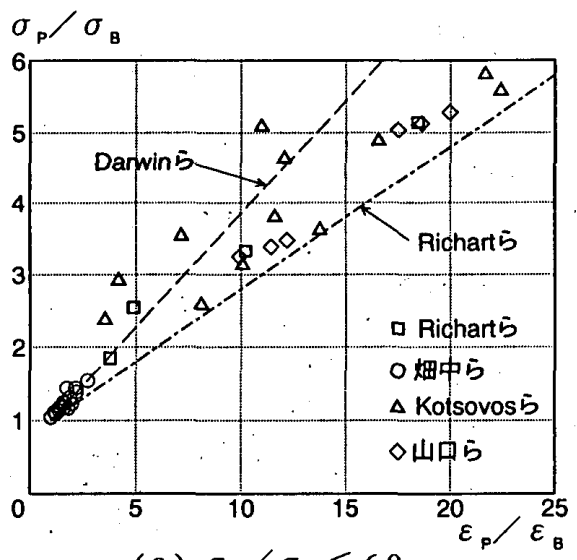

(a) $\sigma_{P} / \sigma_{B} \leqq 6.0$

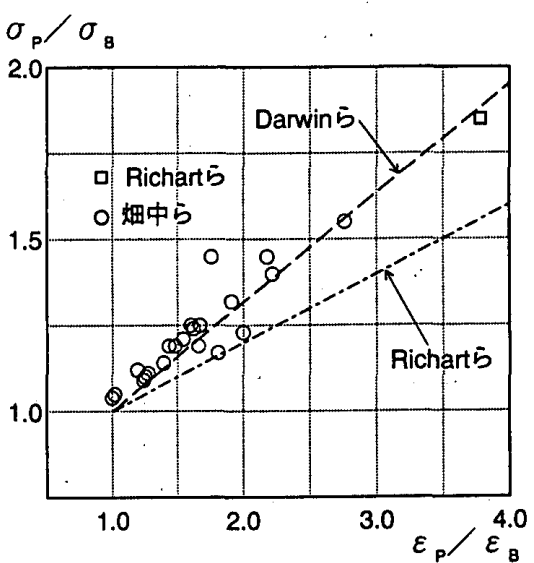

(b) $\sigma_{\mathrm{P}} / \sigma_{\mathrm{B}} \leqq 2.0$

図 4 強度增大率〜ひずみ增大率関係の評価式と実験結果の比較

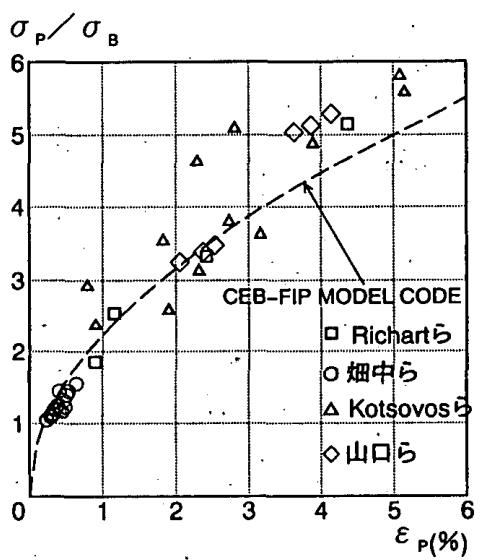

図 5 強度増大率〜強度時ひずみ関 係の評価式と実験結果の比較

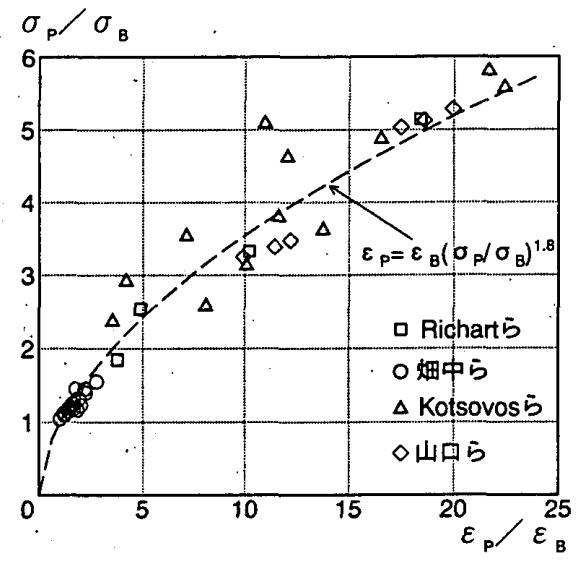

図 6 強度增大率〜ひずみ增大率関係の 提案式と実験結果の比較

$$
\begin{aligned}
& \sigma=\frac{N_{\mathrm{a}} \cdot E \cdot \sigma_{\mathrm{P}}}{N_{\mathrm{a}}-1+\mathrm{E}^{N \mathrm{~B}}} \quad\left(0 \leqq \varepsilon \leqq \varepsilon_{\mathrm{P}}\right) \\
& \mathrm{N}_{\mathrm{a}}=\mathrm{E}_{0} /\left(\mathrm{E}_{\mathrm{O}}-\sigma_{\mathrm{P}} / \varepsilon_{\mathrm{P}}\right) \\
& \mathrm{E}_{\mathrm{O}}: \text { 初期剛性 }
\end{aligned}
$$$$
E=\varepsilon / \varepsilon
$$$$
\sigma=\left[\frac{1}{N_{a}}+\frac{\left(N_{d}-1.0\right) \cdot X}{N_{a}-1.0+X^{N a}}\right] \sigma_{p} \quad\left(\varepsilon>\varepsilon_{P}\right)
$$$$
\mathrm{N}_{\mathrm{a}}=\alpha \cdot \mathrm{N}_{\mathrm{aO}}
$$$$
\hat{N}_{A O}=1+6\left(\sigma_{B} / 100\right)^{0.6} \quad\left(\sigma_{B}<360 \mathrm{kgf} / \mathrm{cm}^{2}\right) \cdots
$$$$
\mathrm{N}_{\mathrm{AO}}=1+\left(\sigma_{\mathrm{B}} / 100\right)^{2} \quad\left(\sigma_{\mathrm{B}} \geq 360 \mathrm{kgf} / \mathrm{cm}^{2}\right) \cdots
$$$$
\alpha=3-2 \sigma_{\mathrm{P}} / \sigma_{\mathrm{B}}
$$$$
(0.7 \leqq \alpha \leqq 1.0)
$$$$
\mathrm{X}=\mathrm{E}_{1}{ }^{0.2} \cdot 2
$$$$
E_{1}=\varepsilon / \varepsilon P
$$$$
\left(\varepsilon / \varepsilon_{\mathrm{s}}<\mathrm{a}\right)
$$$$
E_{1}=\log _{e}\left[b \cdot \varepsilon / \varepsilon_{P}-a+1\right] / b+a \quad\left(\varepsilon / \varepsilon_{B} \geqq a\right)
$$$$
\ldots \ldots \ldots(35)
$$$$
b=0.0055 \cdot\left(\sigma_{B} / 100\right)^{3.8}
$$$$
a=p /\left(\sigma_{B} / 100\right)+1
$$$$
\mathrm{p}=200 /\left(\sigma_{\mathrm{r}}+50\right)
$$

Fafitis .ら"11 は、側圧を受けるコンクリートを対象 として、最大応力到達後の下降域までを含めた主圧縮 方向の応力〜ひずみ関係の表現式として次式を提案し た。(応力の符号は王縮を正とし、単位は $\mathrm{kgf} / \mathrm{cm}^{2}$ )

$$
\begin{aligned}
& \sigma=\sigma_{p} \cdot\left[1-\left(1-\varepsilon / \varepsilon_{p}\right)^{A}\right] \quad\left(0 \leqq \varepsilon \leqq \varepsilon_{p}\right) \cdots(39) \\
& A=E_{0} \cdot \varepsilon_{p} / \sigma_{p} \ldots \ldots \ldots \ldots \ldots \ldots \ldots \ldots \ldots(40) \\
& \sigma=\sigma_{p} \cdot e^{c} \quad\left(\varepsilon>\varepsilon_{p}\right) \\
& c=-k\left(\varepsilon-\varepsilon_{p}\right)^{1.15} \\
& k=2.418 \cdot \sigma_{B} \cdot e^{a} \\
& \mathrm{~d}=-0.1422 \sigma_{\mathrm{r}} / \lambda \\
& \lambda=1+25 \sigma_{r} / \sigma_{B} \cdot\left(1-e^{n}\right) \\
& \mathrm{h}=\left(-\sigma_{\mathrm{B}} / 457\right)^{\circ}
\end{aligned}
$$

Ahmad $5^{10)}$ は三軸応力下を対象として、最大応力到 達後の下降域までを含めた圧縮応力〜ひずみ関係の表現 式として、既往の提案式の係数を $\tau_{0 \mathrm{ct}}$ の関数で評価す る方法を提案した。(次式；応力の符号は圧縮が正)

$$
\begin{aligned}
& \sigma=\frac{\left[\left(A \cdot X+(D-1) \cdot X^{2}\right)\right] \cdot \sigma_{P}}{1+(A-2) \cdot X+D \cdot X^{2}} \cdots \cdots \cdots(47) \\
& X=\varepsilon / \varepsilon_{P} \\
& D=1.111+0.876 \cdot A-4.0883 \tau_{o c t} / \sigma_{P} \\
& A=E_{0} / E_{p}
\end{aligned}
$$

コンクリートの一軸区縮試験結果 ${ }^{341}$ 、㚼中ら 241の 低側区下の三軸圧摍試験結果、及びRichart $5^{28)}$ の高 側圧下の三軸匤縮試験結果と、上記の妇中ら、Fafitis ら及びAhmad らの各提案式による区樎応力〜ひずみ関係 を比較したものを図 7〜図 9 に示す。なお、応力〜ひず み関係の比較に主眼を置くため、与条件である最大応力 点（強度及び強度時のひずみ）は実験結果に一致させ た。また、初期剛性は次式 ${ }^{36)}$ で算定した。

$$
E_{0}=\left(1.14 \sqrt{\sigma_{B}}+5.82\right) \times 10^{4} \quad\left(\mathrm{kgf} / \mathrm{cm}^{2}\right)
$$

图 7 は低強度から高強度までの 3 種類の一軸圧縮試験 結果と比較したものである。高強度になると上昇域が 直楾的になり、ひずみ軟化域は急勾配となる点が特徵で あり、他の多くの一軸圧縮試験も同様の傾向にある。 Fafitis らの提案式は実験と良好に対応しでおり、畑中 らの提案式も強度が約 $400 \mathrm{kgf} / \mathrm{cm}^{2}$ の場合のひずみ軟化域 の形状が多少実験と異なる他は、概ね良好な対応性を示 


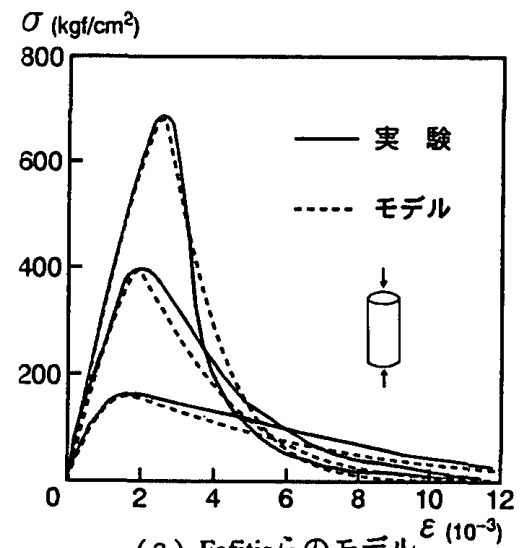

(a) Fafitisらのモテル $\varepsilon_{\left(10^{-3}\right)}$

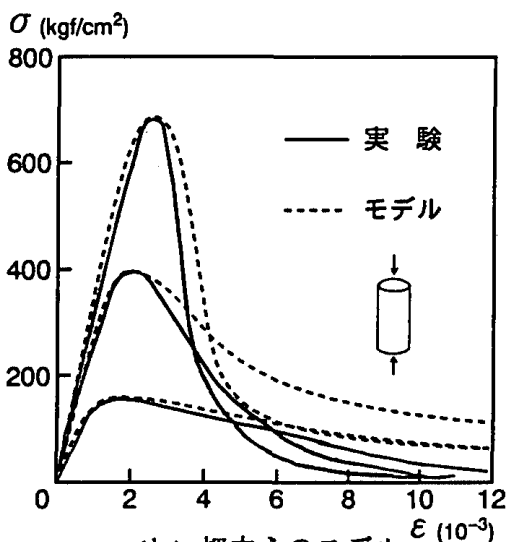

(b) 畑中らのモテル

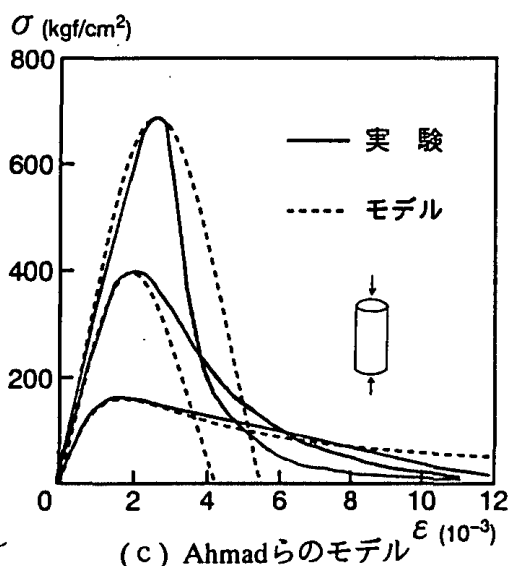

(c) Ahmadらのモテル $\varepsilon_{\left(10^{-3}\right)}$

図7 一軸王縮試験結果 ${ }^{34)}$ と各モデルの比較

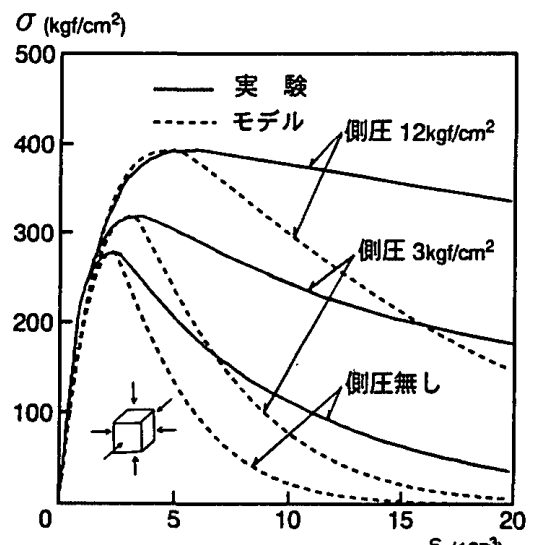

(a) Fafitisらのモテル $\varepsilon_{\left(10^{-3}\right)}$

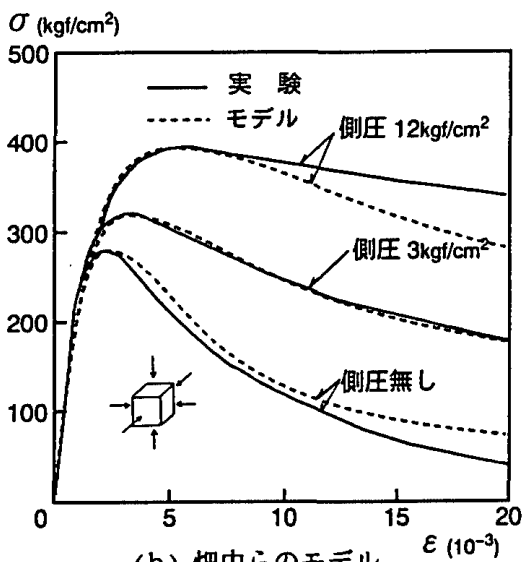

(b) 㚼中らのモテル

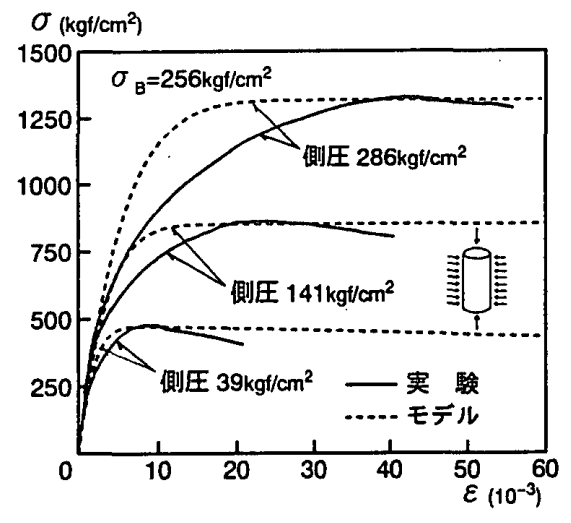

园9高側王三軸圧縮試験結果 ${ }^{28)}$ と Fafitis らのモデルの比較
している。Ahmad らの提案式は高強度ではひずみ軟化域 の対応性が悪い。また、Ahmad らの提案式は、ひずみ 軟化域の形状が初期剛性に極めて敏感て、初期剛性を 10〜20\% 程度変化させただけで、ひずみ軟化域の勾配が 大きく变化してしまう特性がある。

図 8 は娻中らの低側圧下の三軸压縮試験の結果と、 Fafitis ら及び畑中らの提案式を比較したものである。 実験結果より、僅かな側圧の存在がひずみ軟化域の形状 に大きな影響を及ほしていることが分かる。Fafitisら の提案式では、側圧がある場合のひずみ軟化域が実験に 比べてかなり急勾配となる。一方、㚼中らの提案式は、 比較的良好に実験と対応している。

园 9 はRichart らの三軸圧縮試験と Fafitisらの提案 式を比較したものである。㚼中らの提案式は低側王下を 対象としたものであり、ここでは適用範囲外となるため 比較していない。一軸圧樎強度が高い場合に上昇域が直 線的になるのとは対照的に、側王により強度が高くなる 場合には緩やかな曲線となる点が特徴である。Fafitis らの提案式は最大応力近傍まで比較的剛性低下が少な く、㓮性を過大評価する傾向がある。その後は急激に 剛性が低下してほほフラットなひずみ軟化域を示す。
以上のように、既往の提案式は条件によっては対応性 が不十分と言える。そこで、低側王から高側圧までの 応力〜ひずみ曲線の上昇域及び下降域を統一的に表現す るために、前述のAhmad らの式 (47)〜式 (50)において、 係数 XとDの評価方法を改良した。既往の実験結果よ り、応力〜ひずみ曲線の形状には、一軸圧縮強度と側圧 の大きさが顕著な影響を及ほすことが明らかである。 側压の大きさは強度增大率（ $\left.\sigma_{\mathrm{P}} / \sigma_{\mathrm{B}}\right)$ に現れるため、 $\sigma_{\mathrm{B}}$ と $\sigma_{\mathrm{P}} / \sigma_{\mathrm{B}}$ の関数として係数を評価することにし た。実験結果との対応性から係数を決定し、それらの 回熼式より、係数 XとDの評価式として次式を得た。 (応力の符号は圧縮を正とし、単位は $\mathrm{kgf} / \mathrm{cm}^{2}$ )

$$
\begin{aligned}
& \text {-上昇域 }\left(\varepsilon \leqq \varepsilon_{\mathrm{P}}\right) \\
& X=\varepsilon / \varepsilon \\
& D=200 / \sigma_{B}-\left(E_{B} / E_{P}-1\right)^{2} \quad\left(\geqq 1-E_{0} / E_{P}\right) \\
& E_{B}=\sigma_{B} / \varepsilon_{B}
\end{aligned}
$$

-下降域 $(\varepsilon>\varepsilon p)$

$$
\begin{aligned}
& X=\left(1+\frac{\varepsilon-\varepsilon_{P}}{\varepsilon_{P}}\right)^{n} \ldots \ldots \\
& n=0.9+3.4\left(\sigma_{B} / 1000\right)^{2} \ldots \\
& D=1+1800 \cdot\left(\sigma_{P} / \sigma_{B}-1\right)^{2} / \sigma_{B}
\end{aligned}
$$


式 (47)に、上記の式で算定したXと D、及び式 (50)で 算定されるAの值を代入した結果を既往の実験と比較し て図10に示す。一軸圧縮強度や側圧のレベルが異なる 場合も、ほほ良好に実験と対応することが分かる。但 し、高側圧下で下降域が完全に得られている実験データ がほとんど無いため、高側压下ての下降域の適用性は 未確認である。また、下降域の形状は試験体の形状の 違いによる影響を受けることが水野ら日1によって示され ている。これらの点に関しては今後検討が必要である。

\section{5.まとめ}

三軸圧縮下のコンクリートの応力〜ひずみ関係に関し て、既往の実験結果や提案モデルを比較検討した結果、 以下の結論を得た。

1) 三軸圧縮下のコンクリートの強度は、低側圧下では 㚼中らの係数を用いた 0 ttosen の 4 バラメータモデル が実験結果との対応性が良い。高側圧下では実験結果 のバラッキが大きく、上述の 4 バラメータモデルと 大沼らの係数を用いたWillam-Warnke の5パラメータ

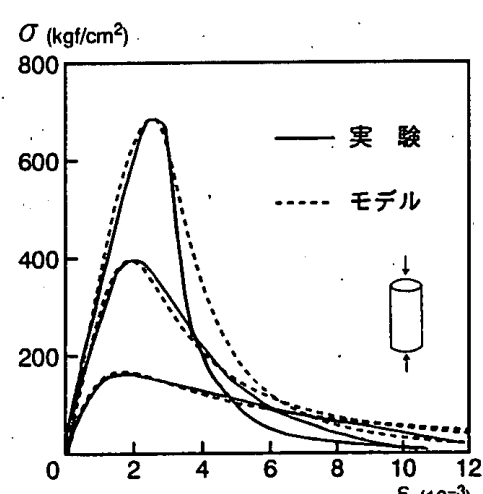

(a) 一軸圧縮試験 $\left.{ }^{34}\right)^{\left(10^{-3}\right)}$

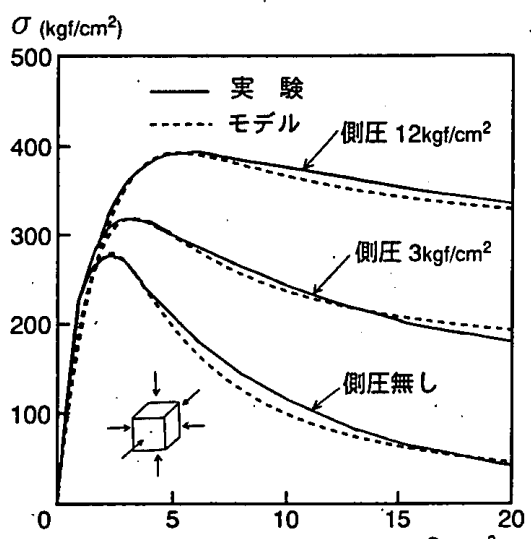

(d) 㚼中らの実驗 ${ }^{24}$

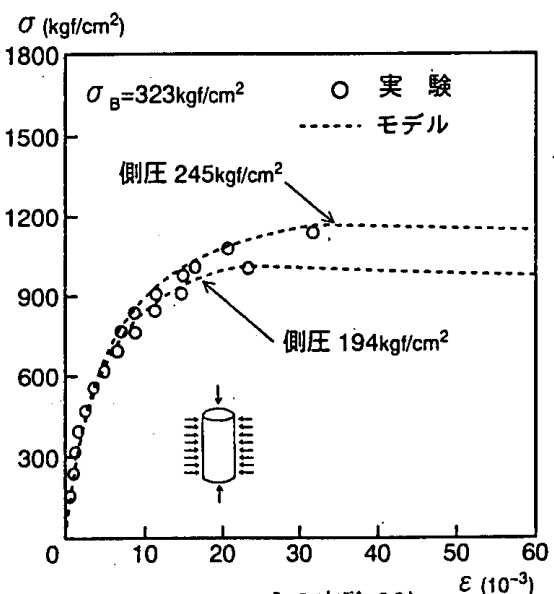

(g) Kotsovosらの实䮦 221

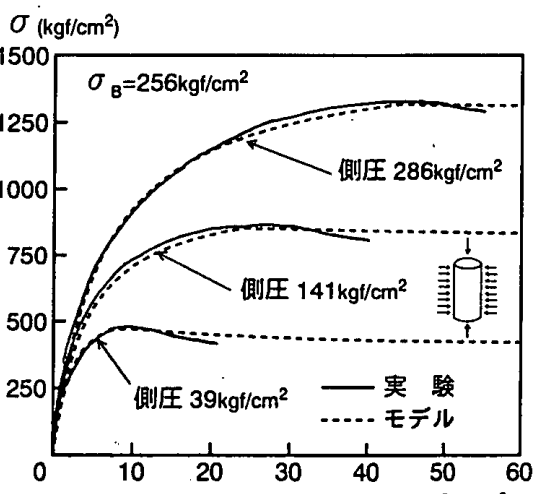

(b) Richartらの実驗 ${ }^{28} \varepsilon_{\left(10^{-3}\right)}$

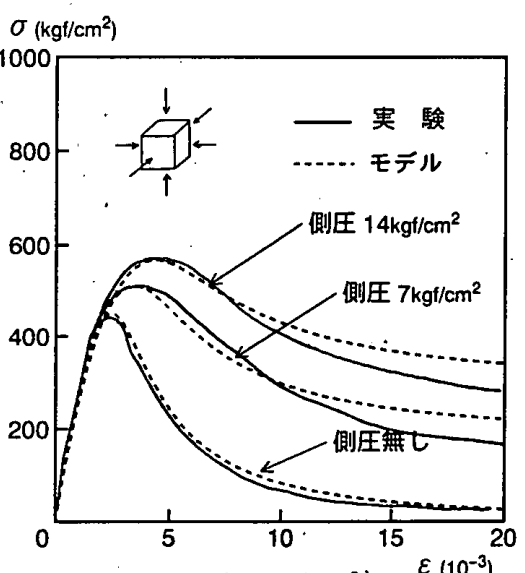

(e) 畑中らの実験 ${ }^{8)}$

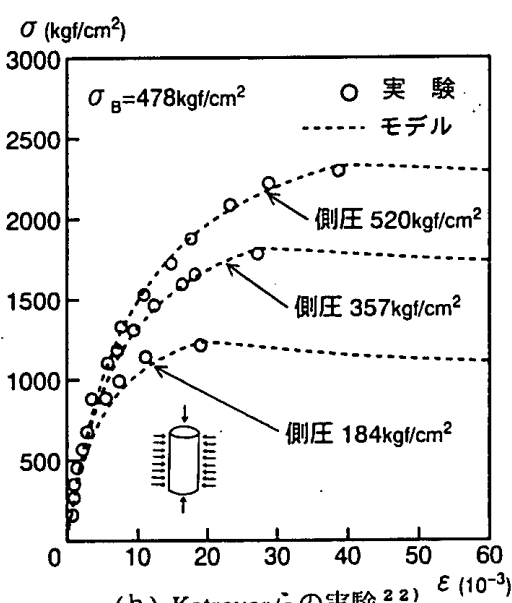

(h) Kotsovos らの実䮦 22$) \varepsilon\left(10^{-3}\right.$

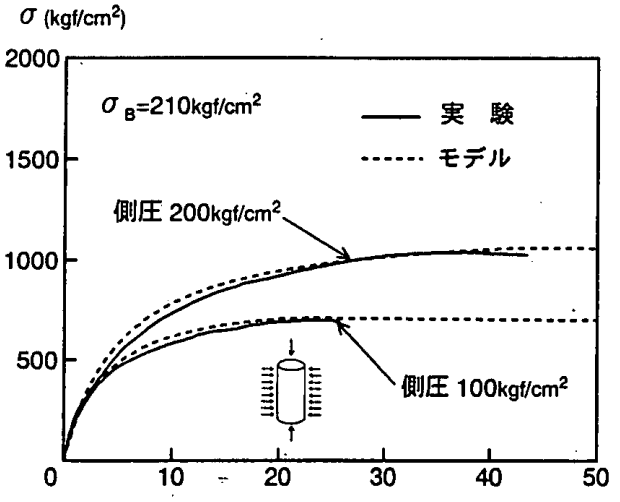

(c) 山口らの実験 ${ }^{21)} \varepsilon\left(10^{-3}\right)$

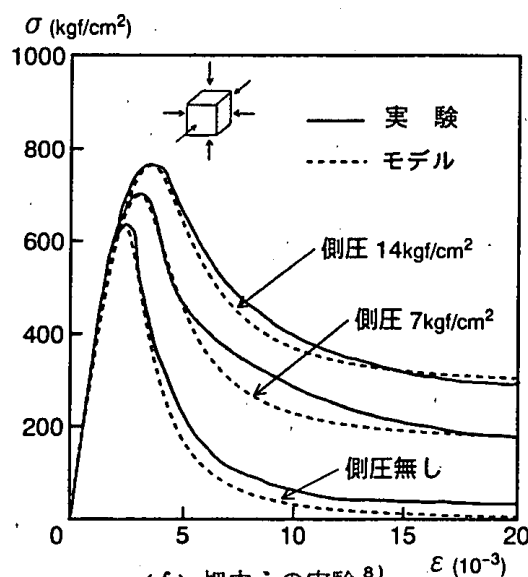

(f) 畑中らの実験 ${ }^{81}$

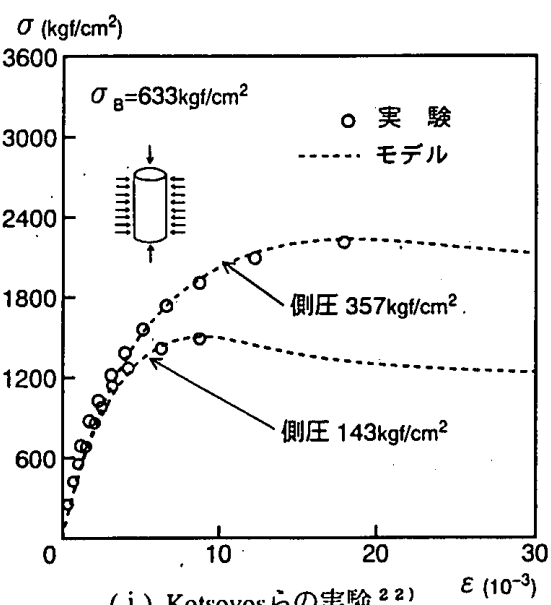

(i) Kotsovosらの奏験 ${ }^{22)} \quad \varepsilon\left(10^{-3}\right)$

図10 既往の種々の実験結果と提案モデルの比較 
モデルが、それぞれ実験データの上限及び下限にほほ 対応する。

2）圧縮強度時のひずみは強度より顕著に增大し、強度 が 2 倍になるとひずみは約 4 倍、強度が 5 倍でひずみ は20倍程度に增加し、ひずみの增加率は強度上昇率の 1.8 烡でほほ評価できる。

3) 三軸圧縮下の応力〜ひずみ曲線の形状には、一軸 氐摍強度と強度增大率が顕著な影響を及ぼす。これら の関数として既往の提案式の係数を算定することで、

一軸圧縮強度や側压レベルが異なる場合の応力〜ひず み曲線の上昇域と下降域をほほ良好に再現できる。

なお、応力〜ひずみ曲線の下降域に関しては、高側圧 下での適用性や試験体の形状の違いによる影響等、今後 さらに検討が必要である。また、実際の解析に適用する 場合には、コンクリートがポアソン効果で圧縮方向と 直交方向に膨張することで、鋼材から拘束力を受ける ことから、ポアソン効果の非線形性の考慮が重要であ る。これに関しては別報にて報告の予定である。

\section{参考文献}

1) Maekawa, K., et al.: Continuum Fracture in Concrete Nonlinearity Under Triaxial Confinement, Proc. of JSCE, No. 460, V-18, pp. 113 122, Feb., 1993.

2) Maekawa, K., et al.:Plasticity in Conrete Nonlinearity Under Triaxial Confinement, Proc. of JSCE, No.460, V-18. pp. $123 \sim 130$, Feb. , 1993.

3) Maekawa,K. et al. :Triaxial Elasto-Plastic and Fracture Model for Concrete, Proc. of JSCE, No. 460, V-18, pp. 131 138, Feb. , 1993

4) 水野英二, 㚼中重光：塑性理論によるコンクリートの圧樎 軟化特性のモテル化，コンクリート工学論文集，第 2 巻， 第 2 号, pp. $85 \sim 95.1991 .7$

5) 水野英二, 㚼中重光：塑性理論によるコンクリートの載荷 経路依存型区樎軟化特性のモデル化，コンクリート工学論文 集，第 3 巻，第 2 号, pp. $1 \sim 13,1992.7$

6) Irawan, P. and Maekawa, K.: Strength and Damage Analysis of Concrete Confined by Steel Casing, Proc. of JSCE, No. 472, V-20, pp. 97 106, Aug., 1993.

7) Irawan, P. and Maekawa,K.: Three Dimensional Analysis on Strength and Deformation of Concrete Confined by Lateral Reinforcement, Proc. of JSCE, No.472,V-20, pp. 107 108, Aug. . 1993.

8) 水野英二，㚼中重光：低側区 3 軸圧摍下の高強度コンク リートの望性変形举動、コンクリート工学年次論文報告集 $12-2$, pp. $719 \sim 724,1990$

9) 畑中重光，他 3 名：3軸圧縮下の普通・高強度コンクリート の応カーひずみモデル，コンクリート工学年次諭文報告集 $13-2$,pp. $31 \sim 36,1991$

10) Ahmad,S.H. and Shah, S.P.: Complete Triaxial StressStrain Curve for Concrete, Journal of the Structural Division, ASCE, Vol.108, No. ST4, pp. 728 742, April, 1982.

11) Fafitis, A. and Shah, S.P. : Lateral Reinforcement for High-Strength Concrete Columns, ACI Special Publication, No.SP-87, pp. 213 232,1985.

12）色部誠，河角誠，安達洋：コンクリート棈造物の塑性解析。 丸瑟, 1985

13) Ottosen, N.S.:A Failure Criterion for Concrete, Journal of the Engineering Mechanics Division, ASCE, Vol.103, No. EM4, pp. 527〜535, Aug., 1977.
14) Willam, K. J. and Marnke, E.P.: Constitutive Model for the Triaxial Behavior of Concrete, International Association for Bridge and Structural Engineering Proceedings, Vol.19, pp. $1 \sim 30,1975$.

15) Hatanaka, S., Kosaka, Y. and Tanigawa, Y.:Plastic Deformational Behavior of Axially Loaded Concrete Under Low Lateral Pressure - An Evaluation Method for Compressive Toughness of Laterally Confined Concretes (Part 1), Trans. of AIJ, No. 377, pp. $27 \sim 40$, July, 1987.

16) Elwi,A.A. and Murray D.W.:A 3D Hypoelastic Concrete Constitutive Relationship, Journal of the Engineering Mechanics Division, ASCE, Vol.105, No. EM4, pp. 623 641, Aug. , 1979.

17）大沼博志，青柳征夫：三軸田䑿医力下におけるコンクリート の強度特性, 電力中央研究所報告, No.381021, 1981.12

18) Mills, L.L. and Zimmerman R.M. : Compressive Strength of Plain Concrete Under Multiaxial Loading Conditions, ACI Journal, Vol.67, No. 10, pp. 802 807, Oct., 1970.

19) Palaniswamy, R. and Shah, S.P. : Fracture and StressStrain Relationship of Concrete Under Triaxial Compression, Journal of the Structural Division, ASCE, Vol. 100, No. ST5, pp. 901 916, May, 1974.

20) Gardner, N.J.: Triaxial Behavior of Concrete, ACI Journal. Vol.66, No.2, pp. 136 146, Feb., 1969 .

21）山口 弘, 藤本一男, 野村設郎 : 高圧 3 軸圧樎応力下におけ るコンクリートの応カーひずみ関係，日本建築学会構造系 論文報告集，第 389号,pp.99〜108,1988.7

22) Kotsovos, M.D. and Newman, J.B. :A Mathematical Description of the Deformational Behavior of Concrete Under Complex Loading. Magazine of Concrete Research, Vol.31, No. 107, pp. 77 90, June, 1979.

23）㚼中重光，他 4 名：低側圧 3 軸圧樎下のコンクリートの整性 変形举動に関する研究（その2：応力ーひずみ特性），日本建 築学会大会学術講演梗概集，構造系，pp. 215 216,1984.10

24）姆中重光, 他 3 名: 各種コンクリートの圧樎勒性の毓一評価 （その1：低侧圧 3 軸压樎実験）日本建築学会大会学術講演 梗概集，構造 II，pp. 189 190,1985.10

25）佐櫒萃典, 下戸芳宽, 渡辺泰志: アンボンド型充填龬管コン クリート槽造の中心区樎性状とその定式化, コンクリート 工学年次論文報告集 $10-3, \mathrm{pp} .355 \sim 360,1988$

26）松浦恒久，薬研地彰：中心圧樎実験に関する文献調查，日本 建筑学会大会学術講演梗概集，構造 II ,pp. 1005 1006, 1992.8

27) Darwin, D. and Pecknold,D.A. Nonlinear Biaxial Stress -Strain Law for Concrete, Journal of the Engineering Mechanics Division, ASCE, Vol.103, No. EM2, pp. 229 241, Apri1, 1977.

28) 崎野健治：コンファインドコンクリートの研究の現状，コン クリート工学, Vo1.30, No. 12,pp. $5 \sim 12,1992.12$

29) 㚼中重光, 他 3 名: 横拘束を受ける高強度コンクリートの䡃 性評価（その1：低側圧 3 軸圧樎時の棈成モテル),日本建築 学会大会学術講演梗概集、棈造 II, pp. 513 514,1990.10

30) 佐藤孝典：円形断面の充填銅管コンクリート輠造における コンファインド効果のメカニスムとそのモデル化，日本建築 学会構造系論文報告集，第 452 号，pp. 149 158,1993.10

31) CEB-FIP Model Code 1990, Bulletin D'Information, No.189, 190a, 190b, Comite Euro-International du Beton, 1988.

32) Popovics, S.:Stress-strain Relations for Concrete under Compression, ACI Journal, Vol.67, No.3,pp. 243 248 , Mar. 1970

33) Kosaka, Y., Tanigawa, Y. and Hatanaka, S. : Experimental Study on Inelastic Stress-Strain Behavior of Steel Fiber Reinforced Concrete under Compression, Trans. of AIJ, No. 337, pp. 15 26, March, 1984.

34) ACI Committe 363 : State-of-the-Art Report on High Strength Concrete, ACI Journal, Vol.81, No.4, pp. $364 \sim$ 411 , July-Aug. , 1984 .

35) 雨宮 篤，野口 博：超高強度鉄筋コンクリート部材の有限 要素解析ブログラムの開発（その1), 日本建築学会大会学術 講演梗概集，構造 II，pp. 639 640,1990.10 